\title{
Pemodelan Generator Uap Berbasis Jaringan Saraf Tiruan dengan Algoritme Pelatihan BPGD-ALAM
}

\author{
Fadhlia Annisa*1, Agfianto Eko Putra ${ }^{2}$ \\ ${ }^{1}$ Prodi Elektronika dan Instrumentasi, Jurusan Ilmu Komputer dan Elektronika, FMIPA UGM \\ 2,3 Jurusan Ilmu Komputer dan Elektronika, FMIPA UGM \\ e-mail: *1 fadhlia.annisa94@ gmail.com, ${ }^{2}$ agfi68@ gmail.com
}

\begin{abstract}
Abstrak
Generator uap merupakan unit plant yang memiliki sistem nonlinear dan kompleks dengan konfigurasi multiple-input-multiple-output (MIMO) yang cukup sulit untuk dimodelkan. Padahal, model generator uap dibutuhkan untuk membuat simulasi seperti operator training simulator (OTS). Tujuan dari penelitian ini yaitu untuk mendapatkan model generator uap yang memiliki 8 parameter luaran dan 9 parameter masukan berbasis jaringan saraf tiruan (JST) menggunakan algoritme pelatihan BPGD-ALAM sehingga diperoleh model yang mendekati sistem nyata. Data diperoleh dari generator uap PT. Chevron Pacific Indonesia, Duri dan dibagi menjadi tiga jenis, yaitu data latih, data validasi dan data uji. Data latih digunakan untuk mendapatkan model setiap luaran melalui proses pelatihan. Verifikasi model juga dilakukan untuk setiap epoch-nya menggunakan data validasi untuk memantau proses pelatihan apakah terjadi overfitting atau tidak. Delapan model JST yang diperoleh diuji menggunakan data uji untuk mengetahui performa dari model. Dari hasil penelitian, diperoleh konfigurasi arsitektur model JST yang berbeda-beda untuk setiap luaran dengan nilai RMSE rendah dari 9,71\% artinya telah dihasilkan model yang mendekati sistem nyata dari generator uap.
\end{abstract}

Kata kunci - Generator uap, Jaringan Syaraf Tiruan, algoritme perambatan balik, laju pembelajaran adaptif, momentum adaptif

\section{Abstract}

Steam generator is unit plant which has nonlinear and complex system with multipleinput-multiple-output (MIMO) configuration which is hard to be modeled. Whereas, steam generator model is very useful to create simulation such as operator training simulator (OTS). The purpose of this research is to obtain model of steam generator which has 8 output parameters and 9 input parameters based neural network (NN) with BPGD-ALAM training algorithm. Data had been taken from steam generator of PT. Chevron Pacific Indonesia, Duri and it is divided into three types, i.e training data, validation data and testing data. Training data was used to obtain model for each ouput through training process. Verification model is also done for each epoch using validation data to monitor training process whether overfitting occurs or not. Eight NN model of each output which is obtained from training and verification, is tested using testing data for getting its performance. From the reseach results, architecture of neural network models are obtained with various configuration for each output with RMSE value under $9.71 \%$. It shows that model which has been obtained, close with steam generator real system.

Keywords - Steam Generator, Neural Network, Backpropagation, adaptive learning rate, adaptive momentum.

\section{PENDAHULUAN}

$\mathrm{G}$ Generator uap air merupakan unit plant yang banyak digunakan dalam dunia industri pada pembangkit listrik baik itu pembangkit listrik tenaga uap maupun pembangkit listrik tenaga nuklir. Generator uap merupakan sistem yang sangat kompleks, nonlinear dan time-variant 
dengan konfigurasi multiple-input multiple-output (MIMO) [1]. Hal inilah yang menyebabkan generator uap sulit untuk dimodelkan. Padahal model generator uap sangat dibutuhkan, contohnya dapat digunakan sebagai operator training simulator (OTS).

Terdapat beberapa metode untuk mendapatkan model matematis dari suatu sistem. Namun harus diketahui jenis sistem yang akan dimodelkan terlebih dahulu, apakah merupakan sistem linear atau nonlinear. Metode yang banyak digunakan untuk memodelkan sistem linear adalah fungsi transfer. Metode ini akan mendeskripsikan perilaku masukan luaran dari sistem [2]. Namun metode ini hanya cocok pada sistem linear, dengan konfigurasi single-input singleoutput (SISO) sehingga sangat sulit untuk memodelkan generator uap yang memiliki konfigurasi MIMO. Terdapat beberapa metode untuk memodelkan sistem nonlinear, yaitu polynomial orthogonal, seri volterra dan volterra-wiener [3]. Namun metode-metode tersebut cukup sulit untuk memodelkan generator uap karena dibutuhkan variabel proses dan informasi yang lengkap dari sistem yang dimodelkan.

Salah satu pendekatan untuk mengidentifikasi model pada sistem nonlinear, yaitu dengan menganggap sistem sebagai black box yang memiliki banyak parameter masukan dan luaran. Sistem black box ini dapat dimodelkan dengan jaringan saraf tiruan (JST) [4]. Tidak seperti metode pemodelan yang telah disebutkan sebelumnya, JST tidak membutuhkan informasi yang banyak dari sebuah proses seperti kedinamisan proses, kenonlinearitasan sistem dan urutan pemrosesan antara hubungan matematika [5].

Dalam penelitian ini akan dilakukan pemodelan terhadap generator uap yang memiliki 8 parameter luaran berdasarkan 9 parameter masukannya menggunakan jaringan saraf tiruan algoritme perambatan balik dengan laju pembelajaran dan momentum adaptif (BPGD-ALAM) sehingga diperoleh model yang mendekati sistem nyata. Model yang dihasilkan akan diimplementasikan pada simulator yang dapat menunjukkan perubahan nilai luaran terhadap perubahan nilai masukan dari generator uap ketika beroperasi.

\section{METODE PENELITIAN}

\subsection{Jaringan Saraf tiruan algoritme perambatan balik dengan laju pembelajaran dan momentum adaptif}

Arsitektur dari jaringan saraf tiruan perambatan balik merupakan multilayer atau banyak lapisan. Arsitektur jaringan saraf perambatan balik yang ditunjukkan pada Gambar 1.

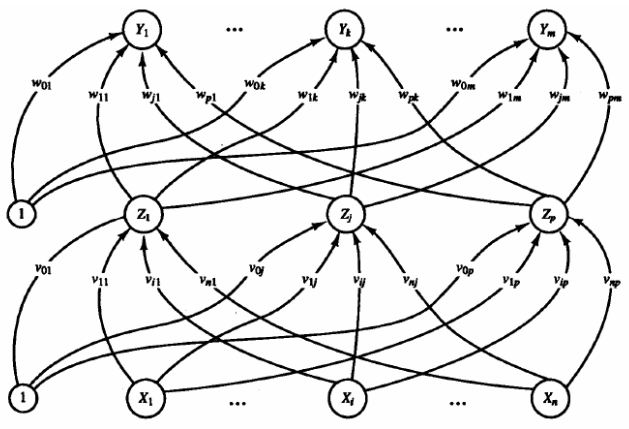

Gambar 1 Jaringan saraf tiruan perambatan balik dengan 1 lapis tersembunyi [6]

Arsitektur JST yang ditunjukkan pada Gambar 1, terdiri dari lapis masukkan (input layer) $x_{i}$, lapis tersembunyi (hidden layer) $z_{j}$, dan lapis luaran (output layer) $y_{k}$. Setiap lapis memiliki neuron-neuron (unit-unit) yang dimodelkan dengan lingkaran. Diantara neuron pada satu lapis dengan neuron pada lapis berikutnya dihubungkan dengan model koneksi yang memiliki bobot-bobot $\mathrm{w}$ dan $\mathrm{v}$. Neuron tersembunyi dan neuron luaran memiliki bias yang memiliki bobot yang bernilai sama dengan satu.

Salah satu teknik yang memodifikasi algoritme perambatan balik konvensional untuk mempercepat pemilihan parameter pelatihan adalah dengan melakukan perubahan nilai laju pembelajaran atau learning rate (LR) dan momentum (M) secara adaptif. Laju pembelajaran

IJEIS Vol. 6, No. 1, April 2016: 1 - 12 
merupakan parameter pelatihan yang digunakan oleh algoritme pelatihan untuk mempercepat konvergensi dari pelatihan. Salah satu parameter pelatihan lainnya untuk mempercepat konvergensi adalah dengan menambahkan koefisien momentum. Penambahan nilai momentum ini bertujuan untuk menyesuaikan arah gradient sehingga dihasilkan arah gradien yang stabil.

Rehman dkk [7] melakukan penelitian untuk mengetahui efek dari perubahan nilai momentum secara adaptif dalam memperbaiki akurasi dari algoritme perambatan balik. Algoritme ini disebut dengan backpropagation gradient descent with adaptive momentum (BPGD-AM). Serupa dengan [7]. Hamid dkk [8] juga melakukan penelitian dalam memperbaiki performa algoritme BPNN konvensional dengan mengubah secara adaptif nilai gain, momentum dan laju pembelajaran yang disebut dengan backpropagation gradient descent with adaptive gain, adaptive momentum and adaptive learning rate (BPGD-AGAMAL). Kedua penelitian tersebut melakukan perubahan nilai laju pembelajaran dan momentum secara adaptif dan setiap neuron pada lapis tersembunyi dan lapis keluaran memiliki nilai laju pembelajaran dan momentum sendiri.

Seluruh proses pelatihan JST dengan algoritme pelatihan backpropagation gradient descent with adaptive learning rate and adaptive momentum (BPGD-ALAM) adalah sebagai berikut.

1. Inisialisasi seluruh nilai bobot, yaitu $v_{i j}$, $w_{j k}$, laju pembelajaran, yaitu $\alpha_{j}, \alpha_{k}$ dan momentum, yaitu $m_{j}, m_{k}$ dengan nilai acak dalam jangkauan $(0,1)$.

2. Vektor masukan $\mathrm{x}_{\mathrm{p}}$ dimasukkan pada neuron masukan.

3. Fase perambatan maju: hitung nilai neuron tersembunyi, $\mathrm{z}$, untuk seluruh $j$ neuron sesuai dengan persamaan (1).

$$
z_{j}=f\left(v_{0 j}+\sum_{i=1}^{n} x_{i} v_{i j}\right)
$$

4. Hitung nilai neuron luaran, y, untuk seluruh $k$ neuron sesuai persamaan (2).

$$
y_{k}=f\left(w_{0 k}+\sum_{j=1}^{p} z_{j} w_{j k}\right)
$$

5. Fase perambatan mundur: hitung informasi galat untuk setiap neuron luaran $\delta_{k}$ dan neuron tersembunyi $\delta_{j}$ sesuai dengan persamaan (3) dan persamaan (4).

$$
\begin{gathered}
\delta_{k}=\left(t_{k}-y_{k}\right) f^{\prime}\left(w_{0 k}+\sum_{j=1}^{p} z_{j} w_{j k}\right) \\
\delta_{j}=\left(\sum_{k=1}^{m} \delta_{k} w_{j k}\right) f^{\prime}\left(v_{0 j}+\sum_{i=1}^{n} x_{i} v_{i j}\right)
\end{gathered}
$$

6. Hitung nilai koreksi bobot untuk setiap neuron luaran, $\Delta w_{j k}$ dan neuron tersembunyi, $\Delta v_{i j}$, sesuai dengan Persamaan (5) dan Persamaan (6) dan koreksi bobot bias neuron luaran, $\Delta w_{0 k}$ dan neuron tersembunyi, $\Delta v_{0 j}$, sesuai dengan Persamaan (7) dan Persamaan (8) sebagai berikut.

$$
\begin{gathered}
\Delta w_{j k}(n+1)=\alpha_{k} \delta_{k} z_{j}+m_{k} \Delta w_{j k} \\
\Delta v_{i j}(n+1)=\alpha_{j} \delta_{j} x_{i}+m_{j} \Delta v_{i j} \\
\Delta w_{0 k}(n+1)=\alpha_{k} \delta_{k}+m_{k} \Delta w_{j k} \\
\Delta v_{0 j}(n+1)=\alpha_{j} \delta_{j}+m_{j} \Delta v_{i j}
\end{gathered}
$$

7. Fase modifikasi bobot: hitung perubahan seluruh nilai bobot untuk seluruh neuron sesuai dengan Persamaan (9), Persamaan (10), Persamaan (11) dan Persamaan (12).

$$
\begin{array}{r}
\Delta w_{j k}(\text { baru })=w_{j k}(\text { lama })+\Delta w_{j k} \\
\Delta v_{i j}(\text { baru })=v_{i j}(\text { lama })+\Delta v_{i j} \\
\Delta w_{0 k}(\text { baru })=w_{0 k}(\text { lama })+\Delta w_{0 k} \\
\Delta v_{0 j}(\text { baru })=v_{0 j}(\text { lama })+\Delta v_{0 j}
\end{array}
$$


8. Fase koreksi laju pembelajaran, $\Delta \alpha$ dan momentum, $\Delta m$, untuk sebanyak $k$ neuron luaran ditunjukkan pada Persamaan (13) dan Persaman (14).

$$
\begin{aligned}
& \Delta \alpha_{k}=\left(t_{k}-y_{k}\right) y_{k}\left(1-y_{k}\right)\left(\sum_{j=1}^{p} w_{j k} z_{j}+w_{0 k}\right) \\
& \Delta m_{k}=\left(t_{k}-y_{k}\right) y_{k}\left(1-y_{k}\right)\left(\sum_{j=1}^{p} w_{j k} z_{j}+w_{0 k}\right)
\end{aligned}
$$

9. Fase koreksi laju pembelajaran, $\Delta \alpha$ dan momentum, $\Delta m$, untuk sebanyak $\mathrm{j}$ neuron tersembunyi ditunjukkan pada Persamaan (15) dan Persamaan (16)

$$
\begin{aligned}
& \Delta \alpha_{j}=\left\lfloor-\sum_{k=1}^{p} \alpha_{j} w_{j k} y_{k}\left(t_{k}-y_{k}\right) y_{k}\left(1-y_{k}\right)\right\rfloor z_{j}\left(1-z_{j}\right)\left(\sum_{i=1}^{p} v_{i j} x_{i}+v_{0 j}\right) \\
& \Delta m_{j}=\left\lfloor-\sum_{k=1}^{p} m_{j} w_{j k} y_{k}\left(t_{k}-y_{k}\right) y_{k}\left(1-y_{k}\right)\right\rfloor z_{j}\left(1-z_{j}\right)\left(\sum_{i=1}^{p} v_{i j} x_{i}+v_{0 j}\right)
\end{aligned}
$$

10. Perubahan nilai laju pembelajaran, $\alpha$ dan momentum, $m$, disesuaikan berdasarakan perubahan nilai RMSE atau root mean square error pada setiap epoch ditunjukkan melalui Persamaan (17), Persamaan (18), Persamaan (19) dan Persamaan (20).

Case 1 : jika RMSE(n) $\geq \operatorname{RMSE}(n-1)$

Case 2 : jika RMSE(n) $<$ RMSE(n-1)

$$
\begin{aligned}
\alpha_{j, k} & =\alpha_{j, k}+\Delta \alpha_{j, k} \\
m_{j, k} & =m_{j, k}+\Delta m_{j, k}
\end{aligned}
$$

$$
\begin{aligned}
& \alpha_{j, k}=\alpha_{j, k}-\Delta \alpha_{j, k} \\
& m_{j, k}=m_{j, k}-\Delta m_{j, k}
\end{aligned}
$$

\subsection{Tahap Pengambilan Data}

Rancangan pengambilan data dilakukan untuk memilih data yang digunakan pada proses pelatihan, proses verifikasi dan proses pengujian. Data yang diperoleh berasal dari data operasi generator uap SG11, Train 5S, PT Chevron Pacific Indonesia, Duri. Data diambil pada 14 Januari hingga 17 Februari 2014. Terdapat 9 parameter masukan yaitu tekanan air, aliran air, tekanan air dalam pipa, aliran udara, kecepatan peniup udara, bukaan katup bahan bakar, tekanan bahan bakar, temperatur bahan bakar dan aliran bahan bakar. Terdapat total 8 parameter yang diukur dari seluruh luaran yang dihasilkan, yaitu energi pembakaran, kadar $\mathrm{O}_{2}$, temperatur cerobong asap, kualitas uap, temperatur uap, tekanan uap, tekanan uap dalam pipa dan aliran uap.

Pengambilan data nyata berasal dari generator uap yang sedang beroperasi dengan pembagian data untuk setiap jenis data ditunjukkan pada Tabel 1.

Tabel 1 Data generator uap yang digunakan

\begin{tabular}{|l|l|l|}
\hline Jenis Data & Jumlah Set Data & Waktu Pengambilan \\
\hline Data Latih & 3.291 & 28-31 Januari 2014 \\
\hline Data Validasi & 1.000 & 28-31 Januari 2014 \\
\hline Data Uji & 17.199 & 14 Januari - 17 Februari 2014 \\
\hline Total & $\mathbf{2 6 . 4 1 1}$ & 14 Januari - 17 Februari 2014 \\
\hline
\end{tabular}

Data yang diperoleh kemudian diunduh dalam bentuk file text dengan format .csv. Kemudian data diperiksa apakah terdapat data yang dianggap tidak valid. Jika ada, maka satu set masukan dan luaran dihapus. Data yang tidak valid disebabkan karena kesalahan pembacaan sensor. Data kemudian disimpan dalam format .xlsx. Dari seluruh data yang dikumpulkan, terdapat tiga jenis data SG 11 dalam dalam rentang waktu yang berbeda dengan total 26.411 set data generator.

\section{3 Tahap proses pemodelan dan verifikasi model}

Model dari jaringan saraf tiruan yang digunakan pada dalam penelitian ini adalah jaringan saraf tiruan MLP atau banyak lapis. Namun, jumlah lapisan pada jaringan dibatasi 
hanya memiliki tiga lapis, yaitu satu lapis masukan, satu lapis tersembunyi dan satu lapis luaran. Masing-masing lapis memiliki beberapa neuron. Jumlah neuron pada lapis masukan berjumlah 9 neuron, lapis luaran dan lapis tersembunyi jumlahnya akan berbeda-beda sesuai dengan model terbaik yang diperoleh. Pada lapis tersembunyi dan lapis luaran terdapat neuron bias yang memiliki nilai 1 yang terhubung dengan seluruh neuron tersembunyi dan neuron luaran melalui hubungan antarkoneksi atau bobot. Setiap neuron pada lapis masukan, lapis tersembunyi dan lapis luaran juga terhubung satu sama lain melalui koneksi bobot. Model JST yang dihasilkan memiliki persamaan seperti yang ditunjukkan pada Persamaan (21).

$$
y_{k}=f\left(w_{0 k}+\sum_{j=1}^{p} f\left(v_{0 j}+\sum_{i=1}^{n} x_{i} v_{i j}\right) w_{j k}\right)
$$

Dengan $f(x)$ merupakan fungsi aktivasi sigmoid biner dengan Persamaan (22).

$$
f(x)=\frac{1}{1+e^{-x}}
$$

Nilai $w_{o k}, w_{j k}, v_{0 j}$ dan $v_{i j}$ merupakan nilai yang merepsentasikan model yang diperoleh dari pelatihan JST menggunakan algoritme pelatihan BPGD-ALAM.

Secara umum, proses pemodelan generator uap dengan dengan JST direpresentasikan dengan Gambar 2.

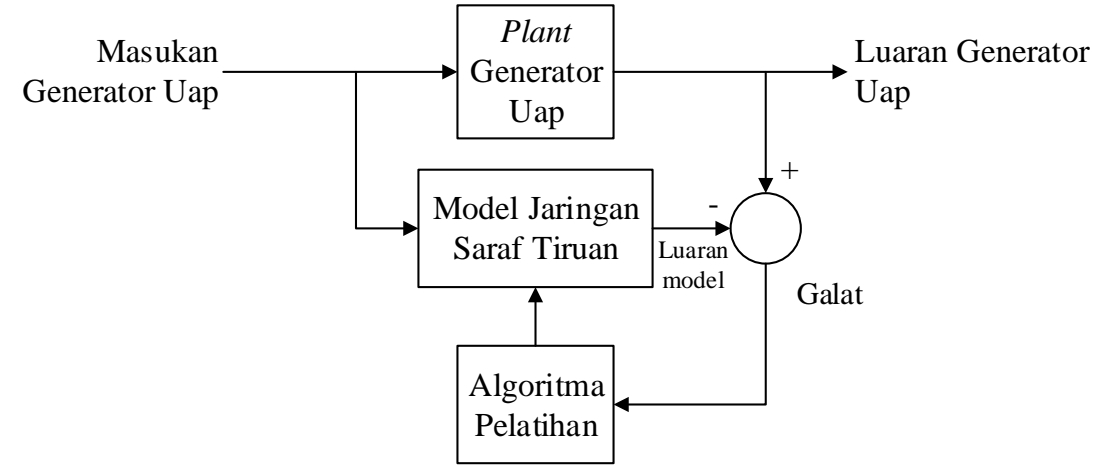

Gambar 2 Representasi proses pemodelan generator uap dengan JST

Berdasarkan Gambar 2, proses pemodelan generator uap dimulai dengan memasukkan masukan generator uap yang sedang beroperasi pada model JST. Model JST akan menghitung luaran dengan nilai masukan dan bobot yang diinisialisasikan secara acak menggunakan fase perambatan maju. Luaran yang dihasilkan model JST akan dibandingkan dengan luaran yang sebenarnya dari generator uap untuk dicari nilai galatnya melalui fase perambatan mundur. Nilai galat tersebut digunakan sebagai informasi galat oleh algoritme pelatihan, yaitu BPGD-ALAM untuk memperbaiki nilai bobot. Proses ini dilakukan berkali-kali hingga luaran model JST menghasilkan nilai yang mendekati luaran yang dihasilkan pada plant generator uap. Tujuan dari proses pelatihan ini yaitu untuk memperoleh bobot akhir yang merupakan representasi model dari generator uap yang digunakan untuk pengujian.

Proses pelatihan dilakukan berulang-ulang sesuai dengan nilai epoch yang ditentukan. Setiap satu epoch akan memproses seluruh data melewati fase perambatan maju, perambatan balik, modifikasi bobot dan koreksi laju pembelajaran dan momentum. Jika satu epoch telah selesai maka dilakukan modifikasi nilai laju pembelajaran dan momentum. Selain itu juga dilakukan proses verifikasi model (dalam JST disebutkan sebagai proses validasi JST). Proses ini akan memproses fase perambatan maju terhadap data validasi yang bertujuan untuk yang menganalisis performa dari model yang dihasilkan dari proses pelatihan. Pada proses pealtihan dan verifikasi, diperoleh galat yang berupa RMSE dan terus dipantau untuk mengetahui apakah selama pelatihan dan verifikasi mengalami overfitting atau tidak.

Root mean square error (RMSE) merupakan akar pangkat dua dari mean square error (MSE) yang menunjukkan ukuran deviasi rata-rata, mirip dengan standar deviasi, namun RMSE berkaitan dengan penyimpangan dari nilai rata-rata nilai sebenarnya [9]. Nilai RMSE yang dihasilkan model menjadi tolak ukur dalam penelitian ini. Semakin kecil nilai RMSE maka 
model yang dihasilkan semakin mendekati system nyata generator uap. Persamaan untuk memperoleh nilai RMSE pada jaringan saraf tiruan ditunjukkan pada persamaan (23).

$$
R M S E=\sqrt{\frac{\sum_{i=1}^{n} x_{i}-x_{t a r g} t}{n}}
$$

\section{4 Tahap pengujian model}

Dalam penelitian ini, dirancang simulator pengujian yang digunakan untuk mensimulasikan model yang dihasilkan dari pelatihan jaringan saraf tiruan. Simulator ini akan menganalisis performa dari model dengan cara menghitung galat yang berupa nilai RMSE antara luaran nyata generator uap dan luaran yang dihasilkan oleh jaringan. Selain itu, simulator ini juga akan menunjukkan perubahan nilai masukan dan luaran yang terjadi seperti ketika generator uap nyata beroperasi dan menunjukkan perbedaan luaran nyata dan luaran model yang dihasilkan.

Pada tahap ini, pertama data pengujian dan lokasi file dari model dimasukkan. Data uji dinormalisasi dan dilanjutkan dengan mengambil nilai bobot akhir dan parameter hasil pelatihan, yaitu jumlah neuron tersembunyi, untuk diimplementasikan sebagai model dari generator uap. Bobot dan parameter tersebut diproses oleh fase perambatan maju. Hasil dari fase perambatan maju adalah nilai luaran seluruh data generator uap. Luaran tersebut kemudian dibandingkan dengan luaran nyata generator dan ditampilkan dalam grafik sehingga terlihat perbedaan antara luaran yang dihasilkan model. Selanjutnya dihitung nilai RMSE untuk mengetahui keakuratan dari model yang dihasilkan.

\section{5 Implementasi Sistem}

Pada penelitian ini dibuat dua antarmuka, yaitu antarmuka pemodelan dan antarmuka simulator untuk melakukan validasi dari model JST. MATLAB R2013a digunakan untuk membuat antarmuka. Antarmuka pemodelan ditunjukkan pada Gambar 3.

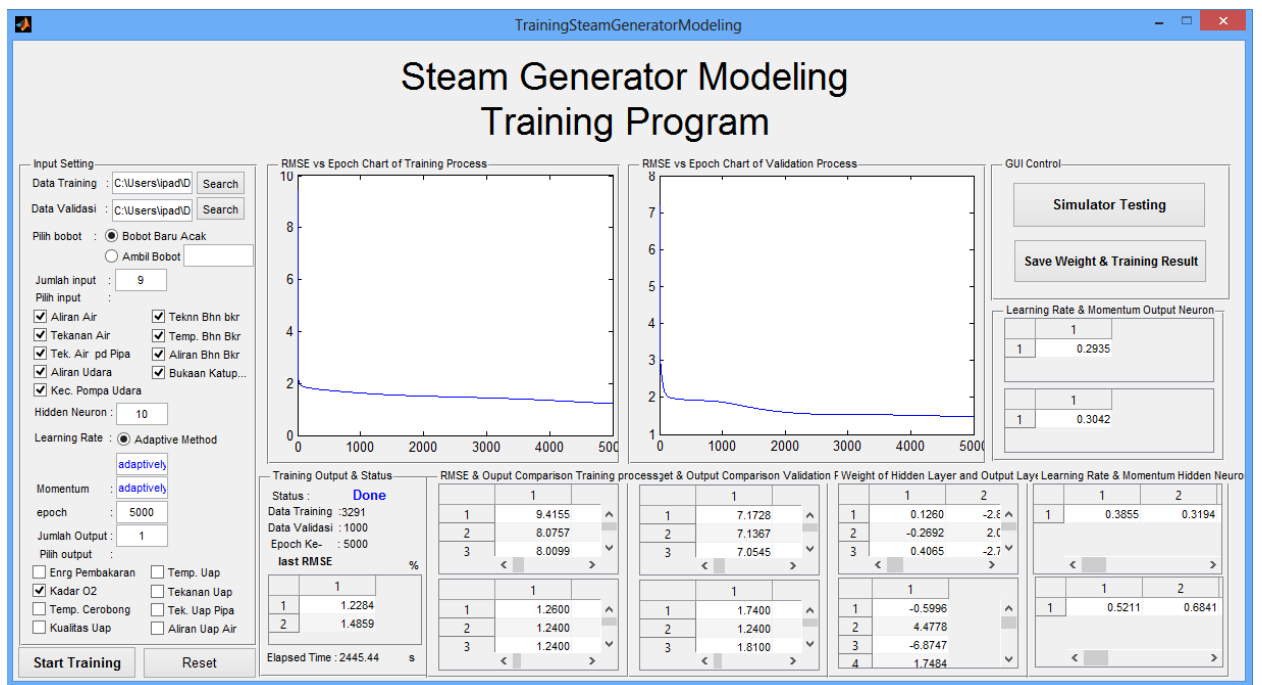

Gambar 3 Antarmuka program pelatihan untuk membangun model generator uap

Antarmuka pemodelan hanya memiliki satu tampilan yang terdiri dari beberapa panel, yaitu panel pengaturan arsitektur JST dan parameter pelatihan, seperti yang ditunjukkan pada sebelah kiri Gambar 3, panel hasil pemodelan yang berupa grafik RMSE data latih dan data validasi. Selain itu terdapat beberapa tabel yang menunjukkan penurunan nilai RMSE, perbandingan nilai luaran yang dihasilkan model dan luaran nyata generator uap, nilai bobot, laju pembelajaran dan momentum. Terdapat juga tombol-tombol seperti start yang berfungsi untuk memulai pelatihan, reset untuk menghapus seluruh data dan save data untuk menyimpan hasil pelatihan dalam format .mat yang dapat digunakan untuk pengujian model. 


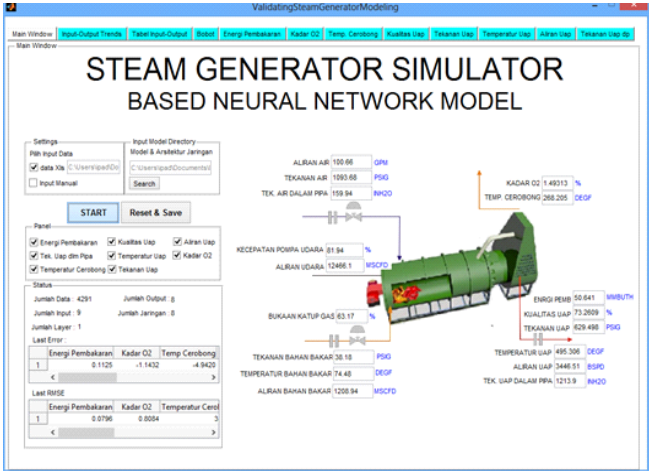

(a)

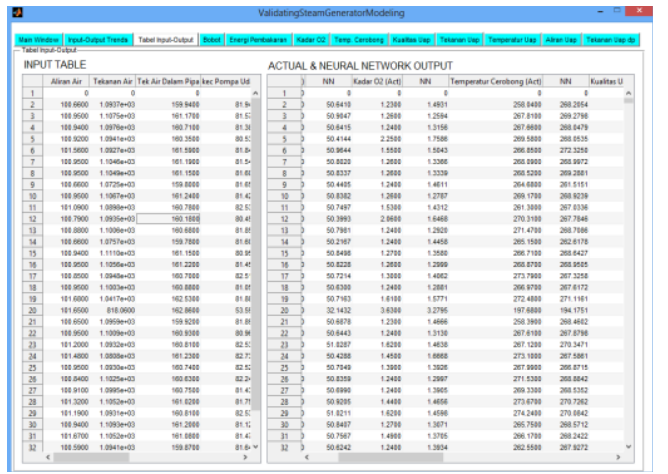

(c)

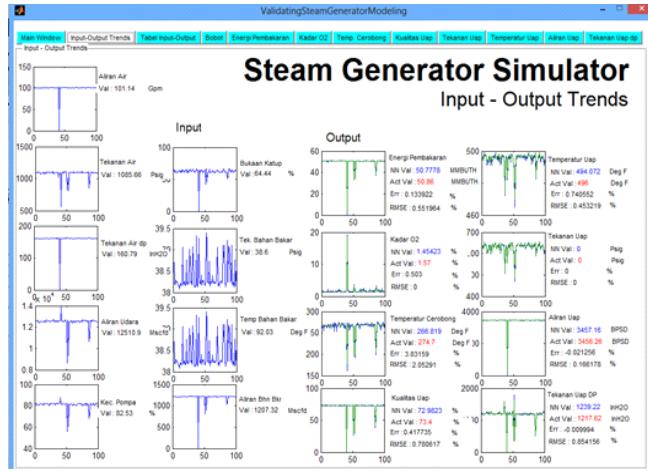

(b)

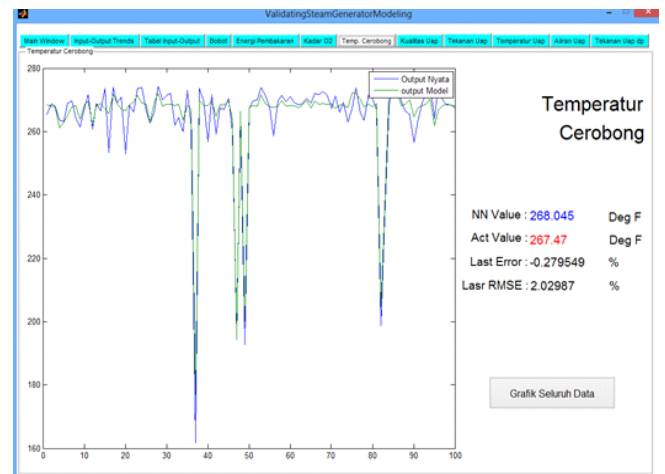

(d)

Gambar 4 Tampilan Antarmuka simulator generator uap (a) tab panel utama, (b) tab panel grafik masukan luaran, (c) tab panel tabel masukan luaran dan (d) tab panel keterangan satu luaran

Antarmuka simulator generator uap yang ditunjukkan pada Gambar 4, dalam satu window memiliki 4 jenis tab panel. Satu tab panel utama seperti yang ditunjukkan pada Gambar 4 (a), 1 tab panel grafik masukan dan luaran ditunjukkan pada Gambar 4 (b), 1 tab panel tabel masukan dan luaran ditunjukkan pada Gambar 4 (c) dan 8 tab panel keterangan sebuah luaran seperti yang ditunjukkan pada Gambar 4 (d). Antarmuka pada simulator generator uap memiliki beberapa bagian yang memiliki fungsi yang hampir sama seperti antarmuka proses pemodelan, yaitu bagian untuk pengambilan data uji bentuk file excel, pengambilan model hasil pelatihan dalam bentuk file .mat, pengaturan parameter jaringan, penampilan data dalam bentuk teks grafik dan tabel.

\section{HASIL DAN PEMBAHASAN}

\section{1 Pengujian Algoritme BPGD-ALAM}

Pengujian ini bertujuan untuk memastikan bahwa algoritme pelatihan jaringan syaraf tiruan dengan laju pembelajaran dan momentum adaptif sudah bekerja dengan baik untuk menghasilkan model JST yang mendekati sistem nyata. Data yang digunakan dalam pengujian ini adalah data latih dan data validasi dari luaran energi pembakaran. Data latih digunakan dalam proses pelatihan dan data validasi digunakan untuk proses verifikasi. Arsitektur JST yang digunakan memiliki konfigurasi 9 neuron masukan sesuai dengan jumlah parameter masukan, 10 neuron tersembunyi dan 1 neuron luaran. Parameter pelatihan berupa jumlah epoch ditentukan sebanyak 100 epoch, inisialisasi bobot, laju pembelajaran dan momentum dilakukan secara acak dengan rentang antara 0 hingga 1 . Kriteria dalam pengujian ini adalah adanya perubahan pada bobot, laju pembelajaran, momentum dan RMSE dari model setiap epoch-nya.

Grafik perubahan bobot, laju pembelajaran dan momentum ditunjukkan pada Gambar 5. 

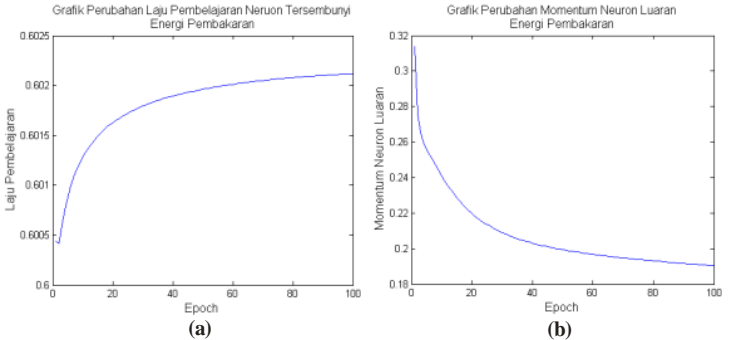

(b)

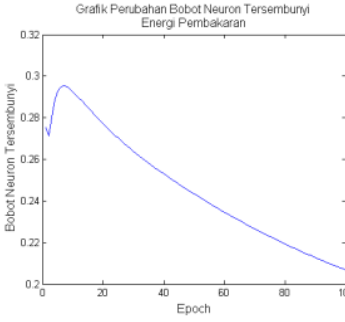

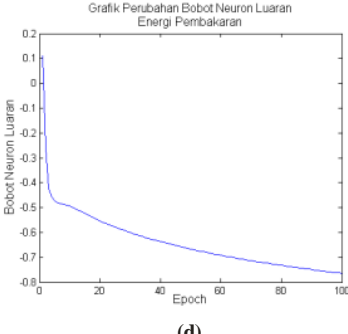

Gambar 5 Grafik perubahan (a) Laju pembelajaran (b) momentum neuron luaran, (c) Bobot neuron tersembunyi dan (d) Bobot neuron luaran

Berdasarkan grafik pada Gambar 5, diketahui bahwa terjadi perubahan pada setiap laju pembelajaran dan momentum dan bobot pada lapis tersembunyi dan neuron luaran namun memiliki perubahan yang berbeda. Perubahan yang terjadi selama proses pelatihan bertujuan untuk mendapatkan nilai yang paling optimum sehingga model yang diperoleh mendekati sistem nyata. Besar kecilnya perubahan yang terjadi menunjukkan dekat atau tidaknya inisialisasi bobot awal dengan bobot optimum. Jika perubahan nilai kecil menunjukkan bahwa inisialisasi awal memiliki nilai mendekati nilai yang optimum. Sebaliknya jika perubahan nilai besar menunjukkan bahwa inisialisasi awal memiliki nilai jauh dari nilai optimum.

Nilai laju pembelajaran dan momentum yang dihasilkan dan berubah selama pelatihan digunakan algoritme BPGD-ALAM untuk memodifikasi bobot hingga diperoleh model dengan nilai RMSE yang semakin mengecil. Penurunan nilai RMSE yang terjadi pada data latih dan data validasi ditunjukkan pada Gambar 6.

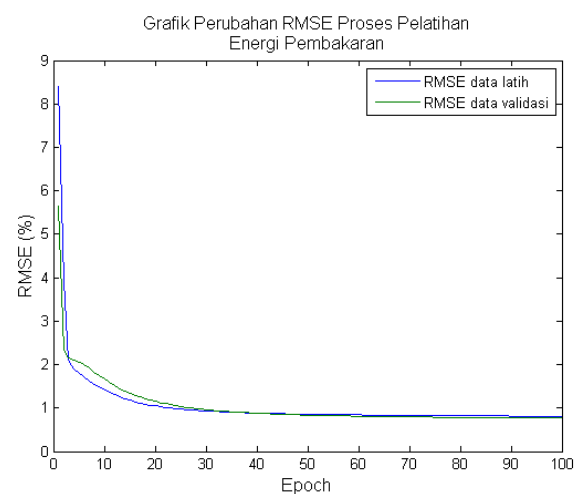

Gambar 6 Grafik perubahan RMSE proses pelatihan luaran energi pembakaran

Berdasarkan hasil pengujian algoritme BPGD-ALAM, terdapat perubahan bobot, laju pembelajaran dan momentum selama proses pelatihan. Selain itu, grafik RMSE yang dihasilkan dari proses pelatihan terus mengalami penurunan seiring dengan kenaikan epoch. Hal ini menunjukkan bahwa algoritme BPGD-ALAM sudah bekerja dengan baik untuk menghasilkan model yang mendekati sistem nyata.

\section{2 Pemodelan dengan konfigurasi JST 8 neuron luaran dalam 1 jaringan}

Setelah pengujian pertama dilakukan yang menunjukkan bahwa algoritem BPGDALAM dapat bekerja dengan baik dalam menghasilkan model JST maka dilakukan pengujian kedua. Pengujian ini yaitu pengujian untuk menghasilkan model JST dengan arsitektur JST yang memiliki konfigurasi 8 neuron luaran dalam 1 jaringan JST. Pengujian ini bertujuan untuk mengetahui apakah konfigurasi JST seperti ini cocok atau tidak untuk memodelkan generator uap.

Pada pengujian ini, Proses pelatihan dan verifikasi model JST dilakukan untuk setiap variasi neuron luaran dengan rentang variasi 1 hingga 20 neuron tersembunyi. Digunakan data latih untuk proses pelatihan dan data validasi untuk proses verifikasi. Konfigurasi JST yang digunakan memiliki 9 neuron masukan, neuron tersembunyi yang divariasi dari 1 hingga 20 dan

IJEIS Vol. 6, No. 1, April 2016 : 1 - 12 
8 neuron luaran. Jumlah epoch yang digunakan berjumlah 1000 epoch. Nilai RMSE data validasi dari setiap luaran generator uap digunakan sebagai kriteria dalam pengujian ini. Nilai RMSE data validasi tersebut disajikan dalam bentuk grafik dan dianalisis berdasarkan kestabilan dari garis yang dihasilkan. Konfigurasi arsitektur JST untuk seluruh luaran dikatakan cocok apabila garis yang dihasilkan dari RMSE validasi untuk setiap luaran memiliki kestabilan, kenaikan dan penurunan yang sama.

Grafik hasil pengujian ditunjukkan pada Gambar 7.

(a) Konfigurasi JST 9-1-8

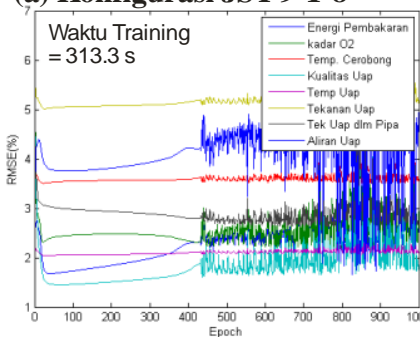

(d) Konfigurasi JST 9-10-8

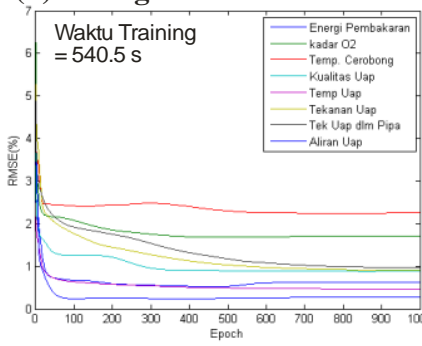

(b) Konfigurasi JST 9-2-8

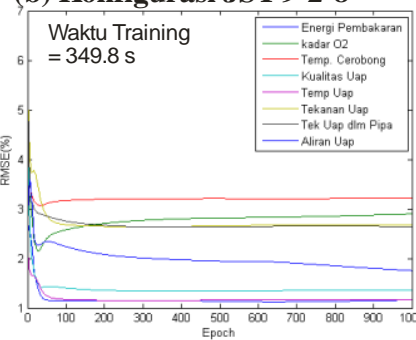

(e) Konfigurasi JST 9-15-8

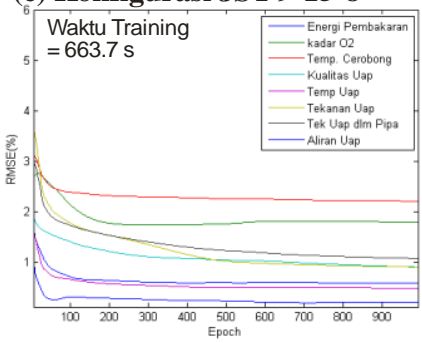

(c) Konfigurasi JST 9-5-8

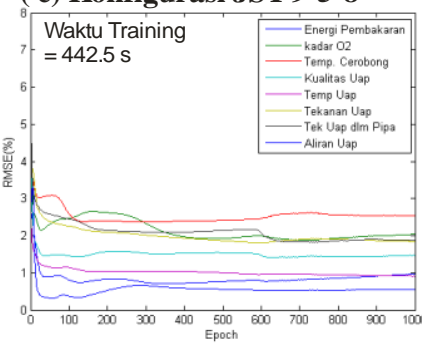

(f) Konfigurasi JST 9-20-8

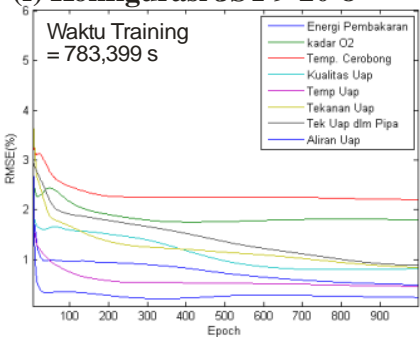

Gambar 7 Grafik RMSE data validasi model seluruh luaran generator uap dengan konfigurasi JST (a) 9-1-8, (b) 9-2-8, (c) 9-5-8, (d) 9-10-8 , (e) 9-15-8 dan (f) 9-20-8

Grafik hasil pengujian yang ditunjukkan pada Gambar 7 menunjukkan bahwa penurunan dan kenaikan grafik RMSE data validasi untuk setiap luaran tidak sama dan cenderung menghasilkan RMSE validasi yang tidak stabil. Sayangnya, variasi dari nilai neuron tersembunyi juga tidak menjamin penurunan yang stabil dari nilai RMSE. Hal ini dapat diketahui dengan membandingkan Gambar 7 (e) dan Gambar 7 (f), bahwa grafik RMSE data validasi 20 neuron tersembunyi tidak lebih stabil dari RMSE validasi 15 neuron tersembunyi. Dapat ditunjukkan dari terdapat model yang mengalami penurunan RMSE data validasi yang cukup signifikan namun pada saat yang bersamaan terdapat model yang mengalami kenaikan nilai RMSE data validasi. Hal ini menunjukkan bahwa konfigurasi ini tidak cocok.

Dari Pengujian ini, dapat diketahui bahwa, arsitektur JST dengan konfigurasi 8 neuron luaran tidak cocok untuk melakukan pemodelan terhadap seluruh luaran generator uap. Oleh sebab itu, pemodelan atau pelatihan untuk setiap luaran harus dilakukan sendiri-sendiri dengan konfigurasi arsitektur JST yang hanya memiliki 1 neuron luaran dalam 1 jaringan JST.

\section{3 Pemodelan dengan konfigurasi JST 1 neuron luaran dalam 1 jaringan}

Pengujian ini dilakukan karena konfigrasi arsitektur JST dengan 8 neuron luaran dalam satu jaringan tidak cocok dilakukan untuk memodelkan generator uap. Pada pengujian ini dilakukan pemodelan dengan konfigurasi JST 1 neuron luaran dalam 1 jaringan. Melalui pengujian ini diharapkan dapat memperoleh 8 model dari luaran generator uap yang paling mendekati sistem nyata. Konfigurasi arsitektur JST yang digunakan pada pengujian ini yaitu terdiri dari 9 neuron masukan dan satu neuron luaran. Nilai neuron tersembunyi divariasi dari nilai 1 hingga 20 neuron dengan interval 1. Digunakan data latih untuk proses pelatihan dan data validasi untuk proses verifikasi. Nilai epoch ditentukan dengan maksimal sebanyak 5000 epoch. Model JST yang diperoleh dari pengujian ini terdiri dari 8 model JST yang kemungkinan memiliki konfigurasi yang berbeda untuk setiap luaran. 
Selama proses pelatihan, terjadi peristiwa overfitting yang terjadi dari beberapa luaran seperti energi pembakaran, kadar $\mathrm{O}_{2}$, kualitas uap dan temperatur cerobong. Hal ini ditunjukkan melalui nilai epoch yang dibutuhkan untuk mendapatkan RMSE data latih terendah berbeda dengan nilai epoch untuk menghasilkan RMSE data validasi terendah. Overfitting sendiri merupakan kejadian ketika algoritme pelatihan terus melakukan pelatihan yang menghasilkan model dengan galat yang semakin kecil pada data latih namun ketika model diujicoba menggunakan data validasi yang sama sekali tidak dikenal oleh algoritme pelatihan, galat yang dihasilkan ternyata tidak semakin mengecil namun justru semakin naik.

Kejadian overfitting ditunjukkan pada Gambar 8 (a). Kejadian ini terjadi pada proses pelatihan untuk luaran kualitas uap dengan 7 neuron tersembunyi. Jika overfitting terjadi maka harus dilakukan early stopping terhadap proses pelatihan dan mengambil model pada epoch dengan nilai RMSE data validasi terendah sebelum terjadinya overfitting. Pada grafik yang ditunjukkan pada Gambar 8 (b), model memang tidak mengalami overfitting, namun proses pelatihan berjalan sangat lambat ketika mencapai epoch ke-3000. Penurunan RMSE validasi dari epoch ke-3001 hingga ke-5000 hanya sebesar 0,0293\%. Hal ini juga dialami oleh sebagian besar luaran dalam proses pelatihan.

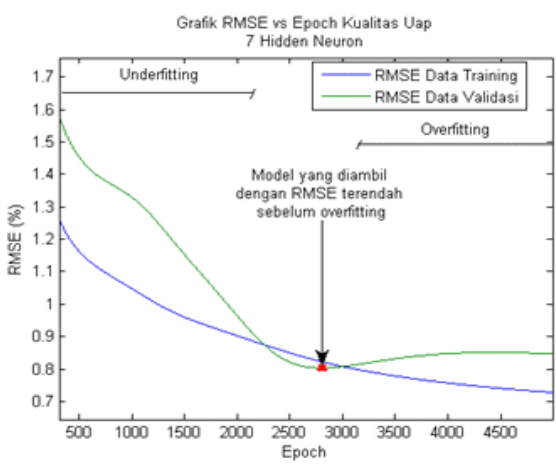

(a)

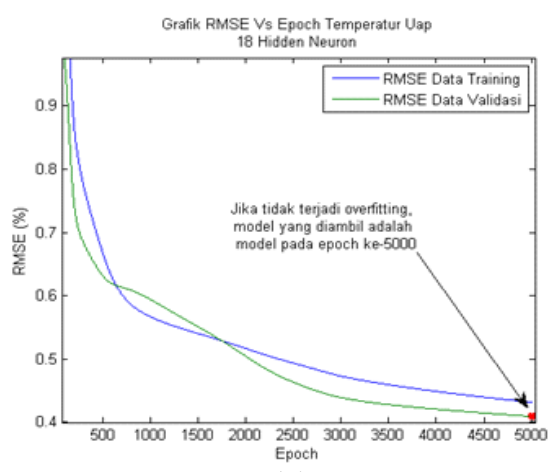

(b)

Gambar 8 (a) model yang diambil ketika terjadi overfitting (b) tidak terjadi overfitting ketika proses pelatihan berlangsung.

Tabel 2 Model JST yang dipilih sebagai model generator uap

\begin{tabular}{|l|c|c|c|}
\hline \multicolumn{1}{|c|}{ Luaran Generator Uap } & $\begin{array}{c}\text { Konfigurasi } \\
\text { Arsitektur } \\
\text { JST }\end{array}$ & $\begin{array}{c}\text { Epoch } \\
\text { Optimum }\end{array}$ & $\begin{array}{c}\text { RMSE Data } \\
\text { Validasi (\%) }\end{array}$ \\
\hline Energi Pembakaran (MMBUTH) & $9-18-1$ & 3951 & 0,4209 \\
\hline Kadar O2 $(\%)$ & $9-19-1$ & 5000 & 1,2837 \\
\hline Temperatur Cerobong $\left({ }^{\circ} \mathrm{F}\right)$ & $9-12-1$ & 793 & 2,0437 \\
\hline Kualitas Uap $(\%)$ & $9-13-1$ & 3184 & 0,6606 \\
\hline Temperatur Uap $\left({ }^{\circ} \mathrm{F}\right)$ & $9-18-1$ & 5000 & 0,4093 \\
\hline Tekanan Uap $(\mathrm{PSIG})$ & $9-12-1$ & 5000 & 0,559 \\
\hline Tekanan Uap dalam Pipa $\left(\mathrm{InH}_{2} \mathrm{O}\right)$ & $9-15-1$ & 5000 & 0,777 \\
\hline Aliran Uap (BSPD) & $9-18-1$ & 5000 & 0,4725 \\
\hline
\end{tabular}

Kegiatan selanjutnya setelah proses pelatihan dan validasi untuk memvariasi jumlah neuron tersembunyi adalah bagaimana memilih model yang terbaik dari seluruh model yang dihasilkan. Dalam hal ini, RMSE validasi digunakan sebagai verifikasi untuk memilih model. Model terbaik yang dipilih adalah model dengan RMSE validasi terendah. Dari seluruh pengujian, dipilih model dengan nilai RMSE data validasi terendah. Model yang dipilih setiap luaran generator uap ditunjukkan pada Tabel 2.

Model yang dihasilkan pada Error! Reference source not found. meskipun telah diverifikasi dengan data validasi, namun waktu pengambilan data validasi dilakukan pada hari yang sama dengan data latih sehingga kemungkinan menghasilkan model dengan galat yang rendah juga besar. Oleh sebab itu, untuk mengetahui apakah model yang dihasilkan benar-benar 
mendekati karakteristik generator uap yang sebenarnya, model harus diuji dengan data uji yang diambil pada waktu yang berbeda yang dilakukan pada pengujian selanjutnya.

\section{4 Pengujian Model JST}

Tahap ini merupakan tahap pengujian atau validasi dari model yang telah diperoleh pada pengujian sebelumnya. Proses yang digunakan pada tahap ini hanya menggunakan fase perambatan maju dengan nilai bobot dan konfigurasi arsitektur JST yang telah dimasukkan. Hasil yan Data yang digunakan adalah data uji dari generator uap SG 11 yang beroperasi pada tanggal yang berbeda. Dalam pengujian ini akan dilihat RMSE, galat minimal dan galat maksimal dari setiap data uji dan dibandingkan dengan yang dihasilkan oleh data validasi. Hasil pengujian dari tahap ini ditunjukkan pada Tabel 3.

Tabel 3 Hasil pengujian model terhadap data SG 11 pada waktu yang berbeda

\begin{tabular}{|c|c|c|c|c|}
\hline \multicolumn{2}{|c|}{ Keterangan Luaran } & $\begin{array}{c}\text { Data SG } 11 \\
28 \text { - 31 Januari }\end{array}$ & $\begin{array}{c}\text { Data SG } 11 \\
14 \text {-17 Januari }\end{array}$ & $\begin{array}{c}\text { Data SG } 11 \\
\text { 14-17 Februari }\end{array}$ \\
\hline \multirow{2}{*}{$\begin{array}{l}\text { Energi Pembakaran } \\
\text { (MMBUTH) }\end{array}$} & Jumlah Data & 4.291 & 8.641 & 8.558 \\
\hline & RMSE (\%) & 0,4378 & 0,2966 & 0,8602 \\
\hline \multirow{2}{*}{ Kadar O2 (\%) } & Jumlah Data & 4.291 & 8.641 & 8.558 \\
\hline & RMSE (\%) & 1,1281 & 0,4511 & 2,3764 \\
\hline \multirow{2}{*}{$\begin{array}{l}\text { Temperatur Cerobong } \\
\left({ }^{\circ} \mathrm{F}\right)\end{array}$} & Jumlah Data & 4.291 & 8.641 & 8.558 \\
\hline & RMSE (\%) & 2,1215 & 3,081 & 2,7323 \\
\hline \multirow{2}{*}{ Kualitas Uap (\%) } & Jumlah Data & 4.291 & 8.641 & 8.558 \\
\hline & RMSE (\%) & 1,4515 & 1,2533 & 1,5323 \\
\hline \multirow{2}{*}{ Temperatur Uap $\left({ }^{\circ} \mathrm{F}\right)$} & Jumlah Data & 4.291 & 8.641 & 8.558 \\
\hline & RMSE (\%) & 0,4056 & 0,7923 & 1,0348 \\
\hline \multirow{2}{*}{ Tekanan Uap (PSIG) } & Jumlah Data & 4.291 & 8.641 & 8.558 \\
\hline & RMSE (\%) & 0,6216 & 0,8937 & 0,9994 \\
\hline \multirow{2}{*}{$\begin{array}{l}\text { Tek. Uap dlm Pipa } \\
\left(\mathrm{inH}_{2} \mathrm{O}\right)\end{array}$} & Jumlah Data & 4.291 & 8.641 & 8.558 \\
\hline & RMSE (\%) & 0,7557 & 0,8435 & 2,0366 \\
\hline \multirow{2}{*}{ Aliran Uap (BSPD) } & Jumlah Data & 4.291 & 8.641 & 8.558 \\
\hline & RMSE (\%) & 0,1439 & 0,0965 & 0,2123 \\
\hline
\end{tabular}

Berdasarkan Tabel 3, RMSE setiap model menghasilkan RMSE dibawah $2 \%$ kecuali model temperatur cerobong yang memiliki nilai yang lebih besar dibandingkan dengan luaran lainnya. Untuk mengetahui penyebabnya, harus diketahui parameter yang mempengaruhi nilai dari temperatur cerobong. Menurut Tim ClearverBrooks [10], terdapat tiga kriteria yang mempengaruhi perubahan nilai temperatur cerobong, yaitu pertama tekanan dan temperatur uap yang dihasilkan, kedua energi pembakaran yang dihasilkan dan ketiga suhu lingkungan dari generator uap. Dari ketiga kriteria tersebut, parameter masukan yang tidak dimiliki dari pemodelan ini adalah suhu lingkungan dari generator uap. Hal inilah yang menyebabkan kenapa luaran temperatur cerobong tidak bisa dibawah $2 \%$, sehingga dibutuhkan parameter masukan temperatur lingkunan untuk memodelkan temperatur cerobong.

Berdasarkan pengujian model yang telah dilakukan untuk tiga jenis data uji, RMSE yang dihasilkan tidak ada yang melebihi 5\%. Mengacu pada penelitian [11] dengan RMSE hasil aimulasi model yang dihasilkan adalah 9,7 \%. Diketahui bahwa telah dihasilkan 8 model parameter luaran berdasarkan parameter masukan generator uap yang cukup baik.

\section{KESIMPULAN}

Berdasarkan hasil pengujian dan analisis dari pengujian, kesimpulan yang dapat diambil adalah sebagai berikut.

1. Dihasilkan model jaringan syaraf tiruan (JST) generator uap yang mendekati sistem nyata dengan konfigurasi JST yang bervariasi.

2. Didapatkan nilai RMSE setiap luaran data validasi terhadap 1000 data, sebagai berikut : energi pembakaran sebesar $0,4209 \%$, kadar $\mathrm{O}_{2}$ sebesar $1,2837 \%$, temperatur cerobong 
sebesar 2,0437 \%, kualitas uap sebesar 0,6606 \%, temperatur uap sebesar 0,4093\%, tekanan uap sebesar $0,559 \%$, tekanan uap dalam pipa sebesar $0,777 \%$ dan aliran uap sebesar $0,4725 \%$.

3. Setelah dilakukan pengujian model terhadap tiga jenis data generator uap pada tanggal yang berbeda, RMSE dari setiap luaran berada dibawah 9,71\% yang menunjukkan bahwa telah dihasilkan model yang cukup baik untuk melakukan simulasi terhadap generator uap.

\section{SARAN}

Berikut saran-saran pengembangan dan penelitian selanjutnya yang sejenis:

1. Penambahan parameter masukan seperti temperatur lingkungan generator uap untuk menghasilkan model yang benar-benar optimum.

2. Penambahan algoritme optimasi seperti GA dan PSO untuk merekomendasikan nilai masukan untuk menghasilkan luaran yang optimum.

\section{UCAPAN TERIMA KASIH}

Penulis mengucapkan terima kasih yang sebesar - besarnya kepada:

1. Tim Intelligence Operation Control PT. Chevron Pacific Indonesia.

2. Seluruh pihak yang telah mendukung kelancaran penelitian ini.

\section{DAFTAR PUSTAKA}

[1] Man, G. N., 2001, A Model Predictive Controller for The Water Level Steam Generators, Journal of The Korean Nuclear Society, Nomor 1, volume 33,102-110.

[2] Dorf, R. C. dan Bishop, R. H., 2011, Modern Control System, Edisi ke-12, Prentice Hall Inc., New Jersey.

[3] Ramamoorthy, P. A., 2002, Nonlinear and Adaptive (Intelligent) System: Analysis, Modeling and Design - A Building Block Approach, University of Cincinnati, Cincinnati.

[4] Willis, M. J. dan Ming, T. T, 2000, Advanced Process Control, http://www.dsea.unipi.it/Members/balestrinow/CP/file/introd APC SPC.pdf, diakses pada 4 September 2014.

[5] Dai, H. dan Thompson, J. W., 1994, use of Neural Networks for Modelling The Steam Generator of A Nuclear Power Plant, Conference Proceedings of Electrical and Computer Engineering, Halifax.

[6] Fausett, L., 1994, Fundamentals of Neural Networks: Architectures, Algorithms, and Applications, Prentice-Hall Inc., New Jersey.

[7] Rehman, M. Z. dan Nawim N.M, 2012, Studying The Effect of Adaptive Momentum in Improving the Accuracy of Gradient Descent Back Propagation Algorithm on Classification Problems, International Conference Mathematical and Computational Biology 2011, Volume 9, 432-439

[8] Hamid, N. A., Nawi, N. M., Ghazali, R. dan Salleh., 2011, Improvements of Back Propagation Algorithm Performance by Adaptively Changing Gain, Momentum and Learning Rate, International Journal on New Computer Architecture and Their Application, Volume 1, Nomor 4, 866-878.

[9] Cimbala, J. M., 2011, Basic Statistics, https://www.mne.psu.edu/me345/Lectures/Basic_Statistics.pdf, diakses tanggal 9 September 2014.

[10] Tim CleaverBrooks, 2011, Boiler Efficiency Guide, http://www.cleaverbrooks.com/ Reference-Center/Insights/Boiler-Efficiency-Guide.aspx, diakses tanggal 30 Januari 2015.

[11] Wright, S. and Marwala, T., 2008, Artificial Intelligence Techniques for Steam Generator Modelling, Computing Research Repository, volume abs/0811.1711, http://arxiv.org/ftp/arxiv/papers/0811/0811.1711.pdf, diakses tanggal 22 Januari 2015.

IJEIS Vol. 6, No. 1, April 2016: 1 - 12 